\title{
17. Irrigators, Water Trading, the Environment and Debt: Buying water entitlements for the environment
}

\author{
Henning Bjornlund, Sarah Wheeler, Jeremy Cheesman
}

Since January 2008, the Australian Government's Water for the Future initiative has secured at least 705 gigalitres (long-term cap equivalent, or LTCE) of surfacewater entitlements through the Restoring the Balance (RTB) environmental water buyback. The Government has $\$ 1.8$ billion remaining in RTB for future entitlement purchases, and to close the 2300-3300 GL environmental watering gap defined in the Guide to the proposed Basin Plan. The Government has indicated a willingness to draw deeper into the public purse to close the environmental watering gap if required. The Government has emphasised that environmental water buybacks have been made, and will continue to be made, from willing sellers. A counterargument is that by conducting environmental water buybacks during the worst drought sequence in 100 years, the Government is predatorily acquiring water from 'forced' rather than 'willing' sellers.

The human, social and economic impacts of selling water to the Government have been considered at the individual, farm and regional community scales. While irrigators who choose to sell some or all of their water entitlements will be financially compensated at some level, they might experience adverse human and social effects from their decision. Moreover, communities that depend on irrigation might experience impacts of water entitlements leaving their region, for example via declining populations and loss of jobs and services. Communitylevel impacts are likely to be more significant in those communities whose economies have a greater reliance on irrigated agriculture, and that produce agricultural commodities with lower marginal value products of water, such as irrigated broadacre. These and other impacts have already been discussed and reported in the context of trading of water entitlements out of individual irrigation districts in the southern Murray-Darling Basin (Edwards et al. 2007; Fenton 2006).

Qualitative analyses of interviews with irrigators indicate that few regard themselves to be willing sellers of water entitlements. Many irrigators claim that they have been 'forced' to sell as a last resort due to financial stress, not least as a result of the current prolonged drought (Kuehne et al. 2010). They suggest that post drought the number of willing sellers may fall off significantly of the price paid for water entitlements by the Australian government does not rise. 
In the context of future environmental water recovery through buyback, the issue is that the impacts of the reduction in total entitlements available for irrigation will depend on how the tenders to purchase water are designed, the extent to which 'willing' sellers will continue to sell entitlements, and how innovative policy makers are going to be to hone the capacity of markets to maximise agricultural output from the available water. Thus, understanding the characteristics of irrigators who sell water entitlements, and the factors they consider in this sale, are core to effective and efficient environmental water recovery by the Government.

Towards this understanding, this chapter provides some insight into the motivations of irrigators who sell water entitlements; what irrigators have historically done with the money they receive from entitlement sales; whether irrigators themselves perceive benefits from having an environmental water market in place; what irrigators think about irrigators who trade water to the Government; and whether there is a widespread belief amongst irrigators that greater environmental flows are necessary in the Murray-Darling Basin (MDB).

The chapter is organised in six parts. The first two parts briefly discuss irrigators' views on water markets and the environment, and how views have changed over time. The next part provides a broad overview of the relationship between debt, selling water entitlements, and what irrigators do with the proceeds. The following part discusses the issue of whether there will be sufficient willing sellers in the future for the Government to meet its environmental waterrecovery objectives. The final part concludes and discusses some alternatives to the current environmental water recovery program.

\section{Irrigator Trade Attitudes}

Various sources (for example, National Water Commission 2010) show that water markets have been important in allowing irrigators to cope with the drought, by either selling or buying water allocations and/or water entitlements. In particular, the allocation market has been instrumental in allowing farmers to manage cash flow and farm risk. Bjornlund has been surveying water traders in key irrigation districts of the MDB over more than two decades. This chapter details irrigator answers to questions asked in surveys in the Goulburn-Murray Irrigation District (GMID) of Victoria in 1998-99, 2003-06, 2008-09 and 201011, the Riverland region of South Australia in 2008-09 and 2010-11, and the NSW Murray in 1998-99 and 2010-11. Irrigator answers provide an overview of irrigators' perceptions of trade issues in the southern Murray-Darling Basin. Tables 17.1 to 17.4 illustrate some key trading questions that have been asked over time, from 1998-99 to 2010-11. 
Since water trading was first introduced in Australia in the mid 1980s, irrigators and their communities have held diverse and shifting opinions about the need for and impact of water markets. Over time, irrigator views towards trading have become more accepting. There has generally been more concern about: 1) entitlement trading than allocation trading; 2) trading out of districts than within districts; and 3) what has been termed speculative trading than trading between irrigators. Table 17.1 suggests that NSW Murray irrigators view the market very differently. Bjornlund (2005) found that: i) sellers in the allocation market agree significantly more with allocation trading than buyers; ii) sellers in the entitlement market agree most with the need for entitlement trading than do buyers; and iii) approximately 85 per cent of those who have traded agreed that water markets are a good idea, while only 48 per cent of those who had never traded as of July 1999 agree.

Table 17.1 Trade attitudes by GMID and NSW Murray in 1998-99 (per cent)

\begin{tabular}{|c|c|c|c|c|c|c|c|c|c|c|}
\hline & \multicolumn{5}{|c|}{$\begin{array}{l}\text { GMID (allocation } \\
\text { buyers and sellers } \\
\text { and non-traders) }\end{array}$} & \multicolumn{5}{|c|}{$\begin{array}{l}\text { NSW Murray } \\
\text { (allocation and } \\
\text { entitlement buyers } \\
\text { and sellers) }\end{array}$} \\
\hline & $S A$ & $A$ & $N$ & $D$ & $S D$ & $S A$ & $A$ & $N$ & $D$ & $S D$ \\
\hline Water trade is a very good idea & 46 & 27 & 13 & 5 & 10 & 48 & 24 & 10 & 7 & 11 \\
\hline $\begin{array}{l}\text { I only agree with temporary transfers } \\
\text { since the water stays on the property }\end{array}$ & 35 & 27 & 12 & 13 & 13 & 31 & 20 & 12 & 18 & 19 \\
\hline $\begin{array}{l}\text { It has to be possible to transfer } \\
\text { water permanently otherwise it } \\
\text { is not possible to make long-term } \\
\text { commitments }\end{array}$ & 27 & 28 & 19 & 13 & 13 & 37 & 27 & 16 & 11 & 9 \\
\hline $\begin{array}{l}\text { Water trade should not be allowed } \\
\text { because it activates otherwise unused } \\
\text { water and reduces annual sales water }\end{array}$ & 9 & 15 & 15 & 28 & 32 & 12 & 13 & 15 & 27 & 33 \\
\hline $\begin{array}{l}\text { Water trade is a good way for some } \\
\text { farmers to get out of irrigation }\end{array}$ & 25 & 39 & 11 & 11 & 14 & 27 & 34 & 15 & 19 & 9 \\
\hline $\begin{array}{l}\text { It is essential to make allocations to } \\
\text { the environment otherwise irrigation } \\
\text { will not be long-term viable }\end{array}$ & 27 & 33 & 21 & 10 & 8 & 17 & 38 & 19 & 15 & 11 \\
\hline $\begin{array}{l}\text { I am willing to reduce annual } \\
\text { sales water allocations in order to } \\
\text { ensure sufficient allocations for the } \\
\text { environment }\end{array}$ & 7 & 20 & 20 & 22 & 31 & 4 & 15 & 17 & 20 & 44 \\
\hline
\end{tabular}

SA = strongly agree; $\mathrm{A}=$ agree; $\mathrm{N}=$ neutral, $\mathrm{D}=$ disagree; $\mathrm{SD}=$ strongly disagree. Notes:

$\mathrm{N}=300$ (GMID); $\mathrm{N}=311$ (Murray).

Source: Based on steering committee reports from LWRDC project USA3 available from <www. waterresearch.net> 
Table 17.2 Trade attitudes in GMID in 2003-06 (per cent)

\begin{tabular}{l|l|l|l|l|l}
\hline & $S A$ & $A$ & $N$ & $D$ & $S D$ \\
\hline Water trading should be allowed only within districts & 52 & 10 & 14 & 4 & 20 \\
\hline $\begin{array}{l}\text { Export out of districts imposes additional cost on remaining } \\
\text { irrigators }\end{array}$ & 65 & 15 & 11 & 3 & 5 \\
\hline $\begin{array}{l}\text { Export out of districts has significant social flow-on effects } \\
\text { within the district, with loss of businesses, development, jobs } \\
\text { and population }\end{array}$ & 66 & 15 & 10 & 4 & 5 \\
\hline $\begin{array}{l}\text { If water and land are separated, I fear that big corporations will } \\
\text { purchase large volumes of water and control who gets it and at } \\
\text { what price }\end{array}$ & 68 & 14 & 8 & 3 & 6 \\
\hline $\begin{array}{l}\text { Trading in water should be allowed only between people who } \\
\text { own land on which the water can be used }\end{array}$ & 79 & 8 & 5 & 3 & 5 \\
\hline $\begin{array}{l}\text { I am sceptical about the Living Murray Process -it looks as if the } \\
\text { objective is to trade-off country voters for city voters }\end{array}$ & 57 & 17 & 14 & 3 & 8 \\
\hline $\begin{array}{l}\text { It is essential to make allocations to the environment otherwise } \\
\text { irrigation will not be long-term sustainable }\end{array}$ & 19 & 15 & 30 & 12 & 24 \\
\hline $\begin{array}{l}\text { We would be willing to reduce our seasonal allocations in order } \\
\text { to ensure sufficient allocations for the environment }\end{array}$ & 9 & 8 & 16 & 14 & 54 \\
\hline $\begin{array}{l}\text { We would be willing to give water to the environment as a } \\
\text { reasonable contribution to improve conditions and as part of a } \\
\text { wider community effort }\end{array}$ & 8 & 9 & 20 & 12 & 51 \\
\hline
\end{tabular}

Note: $N=1068$. Source: Based on data from Bjornlund (2007).

Table 17.3 Trade attitudes in GMID and Riverland in 2008-09 (per cent)

\begin{tabular}{l|l|l|l|l|l|l|l|l|l|l|l}
\hline & \multicolumn{3}{l}{ GMID } & \multicolumn{3}{l|}{ Riverland } \\
\hline & $S A$ & $A$ & $N$ & $D$ & $S D$ & $S A$ & $A$ & $N$ & $D$ & $S D$ \\
\hline $\begin{array}{l}\text { People who buy and sell water } \\
\text { regularly are just greedy for money }\end{array}$ & 3 & 38 & 17 & 35 & 7 & 2 & 37 & 16 & 39 & 7 \\
\hline $\begin{array}{l}\text { I would seriously consider selling my } \\
\text { water if I was offered substantially } \\
\text { more than market price }\end{array}$ & 5 & 37 & 12 & 40 & 6 & 4 & 28 & 8 & 47 & 14 \\
\hline $\begin{array}{l}\text { If I had unused water I would rather } \\
\text { use it to expand my irrigation than sell } \\
\text { it at an attractive price }\end{array}$ & 2 & 29 & 16 & 46 & 7 & 2 & 39 & 20 & 36 & 2 \\
\hline $\begin{array}{l}\text { If I had unused water I would probably } \\
\text { not sell it because I would expect the } \\
\text { price to increase in the future }\end{array}$ & 2 & 32 & 23 & 37 & 2 & 2 & 28 & 20 & 47 & 4 \\
\hline $\begin{array}{l}\text { When I retire I will move to an area } \\
\text { that has more to offer }\end{array}$ & 1 & 58 & 17 & 23 & 1 & 2 & 56 & 14 & 25 & 3 \\
\hline $\begin{array}{l}\text { If I sold my water I would be letting } \\
\text { my community down }\end{array}$ & 2 & 24 & 7 & 53 & 14 & 2 & 38 & 14 & 42 & 5 \\
\hline
\end{tabular}

Notes: $\mathrm{N}=300$ in GMID; $\mathrm{N}=324$ in Riverland.

Source: Based on data from RIRDC project by Bjornlund and Cheers; data not previously published. 
17. Irrigators, Water Trading, the Environment and Debt: Buying water entitlements for the environment

Table 17.4 Trade attitudes in New South Wales, Victoria and South Australia, 2010-11 (per cent)

\begin{tabular}{|c|c|c|c|c|c|c|c|c|c|c|c|c|c|c|c|}
\hline & \multicolumn{5}{|c|}{ NSW } & \multicolumn{5}{|c|}{ Victoria-GMID } & \multicolumn{5}{|c|}{ SA } \\
\hline & $S A$ & $A$ & $N$ & $D$ & $S D$ & $S A$ & $A$ & $N$ & $D$ & $S D$ & $S A$ & $A$ & $N$ & $D$ & $S D$ \\
\hline $\begin{array}{l}\text { I believe water trading } \\
\text { has been a good thing } \\
\text { for farming }\end{array}$ & 7 & 38 & 12 & 23 & 17 & 8 & 32 & 15 & 26 & 18 & 7 & 49 & 14 & 21 & 7 \\
\hline $\begin{array}{l}\text { Trading water allows } \\
\text { me to cope with } \\
\text { seasonal uncertainty }\end{array}$ & 14 & 58 & 8 & 13 & 5 & 16 & 57 & 8 & 13 & 4 & 11 & 58 & 17 & 9 & 1 \\
\hline $\begin{array}{l}\text { We would be willing } \\
\text { to have our seasonal } \\
\text { allocations reduced to } \\
\text { ensure sufficient water } \\
\text { for the environment }\end{array}$ & 1 & 5 & 9 & 42 & 41 & 0 & 9 & 7 & 41 & 41 & 0 & 17 & 10 & 42 & 28 \\
\hline $\begin{array}{l}\text { Most irrigators } \\
\text { think increasing } \\
\text { environmental water } \\
\text { flows is a good thing }\end{array}$ & 1 & 21 & 10 & 48 & 19 & 1 & 20 & 11 & 47 & 16 & 5 & 64 & 11 & 17 & 3 \\
\hline $\begin{array}{l}\text { It is essential to make } \\
\text { allocations to the } \\
\text { environment otherwise } \\
\text { irrigation will not be } \\
\text { long-term sustainable }\end{array}$ & 6 & 38 & 12 & 28 & 12 & 4 & 39 & 14 & 32 & 8 & 8 & 71 & 7 & 10 & 1 \\
\hline $\begin{array}{l}\text { I am well informed } \\
\text { about the trading rules } \\
\text { in my district }\end{array}$ & 16 & 68 & 6 & 6 & 2 & 15 & 68 & 6 & 9 & 2 & 8 & 78 & 4 & 7 & 1 \\
\hline
\end{tabular}

Notes: $\mathrm{N}=274$ (SA); $\mathrm{N}=358$ (Vic.); $\mathrm{N}=313$ (NSW).

Source: Based on data from ARC Linkage grant by Wheeler, Bjornlund and Shanahan; data not previously published.

During more than a decade of surveying, four concerns about water trading have been consistently raised by irrigators: 1) the sale of entitlements from irrigation regions will result in irrigation costs rising for the remaining irrigators; 2) if entitlements are traded away from farmland it might be left uncultivated and become infested with weed and pests, which is a nuisance for neighbouring farmers; 3) if entitlements are traded away from farmland then the value of the land could decline - as a result, the council rate base will be reduced leading either to higher rates for remaining irrigators or to less services; and 4) if entitlements are sold out of a local area then farm production might decline. This could result in a loss of both on and off-farm jobs, which may in turn lead to regional decline in population and services.

Despite these concerns, irrigators have widely adopted water trading over time, in particular the trading of allocations. When water trading commenced in the mid 1980s, only a few per cent of farm businesses traded each season. In the late 1990s and 2000s, as water scarcity increased and farmers became more familiar 
with water trading, market participation rates increased markedly. Research within the GMID indicates that in the early 2000s up to 60 per cent of farm businesses traded water in some form each season, while less than 10 per cent had never engaged in water trading (Wheeler et al. 2009).

There is increasing evidence that the allocation market has become more competitive over time, with more than 30 per cent of the water applied in the field within the GMID being purchased in that market (Bjornlund and Rossini 2008; Wheeler et al. 2010a). There has also been an acceleration in entitlement trading, with the percentage of the total entitlement base traded within the GMID increasing from less than 1 per cent prior to 1998-99 to 4.5 per cent by 2007-08 (Bjornlund and Rossini 2010). In the GMID the 4 per cent cap on entitlement trade out of districts has been reached in successive years between 2007 and 2010, which suggests that total entitlement trade would have exceeded 4.5 per cent if this cap was not in place.

Water trading is thus having an increasing influence on who use and own water. There is clear evidence to suggest that irrigators have used water markets to manage the adjustment process and to manage water scarcity and production risk with respect to water supply (Bjornlund 2002, 2004, 2006). Despite the early reluctant acceptance of water trading, there is now a clear understanding within the irrigation community that without water trading the socioeconomic impact of the current drought would have been much harsher.

\section{Irrigator Attitudes to the Environment}

In general, irrigators agree with statements about the importance of, and need for, greater environmental flows in the Murray (Bjornlund 2005; Tisdell and Ward 2003). Over time however there have been significant declines in irrigators' acceptance of environmental needs. Tables 17.1, 17.2 and 17.4 summarise irrigators' responses to two questions - one about the need for more environmental flows in the River Murray and one about their preparedness to contribute to environmental flows by reducing their seasonal allocations. In the GMID, the percentage of irrigators agreeing with both statements was highest in 1998-99. Between the 1998-99 and 2010-11 surveys, irrigators' stated willingness to contribute towards environmental flows dropped from 30 per cent to 10 per cent amongst NSW and GMID irrigators. Over the same period, the percentage of irrigators agreeing with the need for more environmental flows declined from 60 per cent to 43 per cent in the GMID, and from 55 per cent to 44 per cent in New South Wales. Although no significant difference was found between NSW and GMID irrigators' attitudes to environmental flows, it seems that SA irrigators hold significantly different views to their upriver counterparts. In 2010-11, nearly 80 per cent of SA irrigators believed in the need to increase environmental flows, while about 17 per cent agreed with some form of voluntary uncompensated reduction in seasonal allocations. 
These findings suggest that irrigators' willingness to sacrifice their own water allocations for the environment has been falling sharply over the past decade as water scarcity increased and the national water-reform policy process intensified from a point of discussion to reality. Drought and the real extent of the sustainable diversion limit (SDL) 'cuts' have fostered strong resentment amongst irrigators for what is regarded as a Basin Plan Guide that aims solely to meet the environmental watering requirements defined by federal bureaucrats. However, it may be a real surprise to many that over 10 per cent of southern MDB irrigators surveyed from August to the first week of October 2010 agreed that they were willing to see some of their water allocations sacrificed (without compensation) to ensure enough water for the environment.

\section{The Relationship between Debt and Selling Water}

Qualitative research suggests that farm debt is a main reason for irrigators selling water to the Government for environmental flows (ABARE 2009; Kuehne et al. 2010). There is no doubt that some farmers do sell water as a measure of last resort; however, the sale of water to finance or retire farm debt is not a new phenomenon - nor is it associated exclusively with environmental water purchases by the Government. Surveys of irrigators trading during the 1987-94 period within the GMID and Riverland found that cash-flow management was the main reason for 57 per cent of GMID irrigators selling water, and 71 per cent within the Riverland. Consistent results were observed in 1994-96, when 61 per cent of GMID and 58 per cent of Riverland irrigators gave this reason for selling (Bjornlund 1999). A similar survey of water sellers within Murray Irrigation Limited from 1990 to 1999 found that 52 per cent of sellers cited financial reasons as their main motivation for selling their entitlements (Bjornlund 2000).

The relationship between farm debt and selling water is complex. To fully understand the issue one needs to consider all the possible influences on why farmers sell water back to the Government. Several studies have looked at this relationship in detail. In 2008-09, 624 irrigators in the Riverland and the GMID were surveyed and asked about their willingness to sell water to the Government. Wheeler et al. (2010b) sought to understand what influenced irrigators in the two regions to sell their water. Farm debt was a strong, significant influence on GMID irrigators' willingness to sell. It was found that the higher the total farm debt, the higher was the likelihood that they were thinking of selling. Indeed, the higher the debt level, the higher was the percentage of their total water entitlements they were considering selling. This was not the case, however, for Riverland irrigators, where no significant association between debt and willingness to sell was found. 
Marsden Jacob Associates (2010) surveyed 1021 farmers (808 irrigators and 213 dryland farmers) in 11 regions of the Basin between March and April 2010. This project sought to explore how irrigators may exit the industry under proposed water-entitlement cuts of up to 40 per cent of LTCE allocations. Overall, irrigation farms were found to be conservatively geared, with farm equity ratios generally near 80 per cent or greater. Over the past five years, however, average annual returns from farming have been low to negative due to drought. The average gross margin return on farm assets for horticulture, broadacre, livestock, dairy and mixed farms interviewed is in the range of -2 per cent to 2 per cent. Adding debt and interest costs will mean the average annual return on assets during the past five years has been negative for the majority of farms surveyed. This is an unsustainable cash-flow situation, and places a significant constraint on the ability of farmers to service farm debt and grow their operations. Cash flownot assets and gearing - now appears to be the fundamental challenge for most farmers.

Marsden Jacob Associates (2010) also found that younger farmers have progressively higher debt than their older counterparts, and that-holding age and farm type constant - increasing farm debt was systematically linked to lower subjectively assessed personal wellbeing and future optimism scores. Moreover, holding all other factors (such as age, farm type, farm size, and so on) constant, in response to permanent reductions in irrigation allocations, irrigators with higher debt stated they would be more likely to: 1) seek to exit irrigation altogether; ${ }^{1}$ and 2 ) restructure their farming operations. ${ }^{2}$

One of the main findings from these studies is that there is a wide range of influences on selling water. Farm debt does play a part, but irrigators' attitudes, values and wellbeing appear to be the most significant and strongest influences on decisions to sell water or exit the industry. For example, the survey undertaken by Marsden Jacob Associates found that the strongest predictor of the likelihood of an irrigator stating they would exit farming in response to permanent reductions to LTCE allocations was their Deakin wellbeing score. ${ }^{3}$

These studies show that how irrigators feel about their relationship with their community, their family, their health, and their standard of living counts more when they plan what to do with their farm and their water than many other

1 Significant at the 1 per cent level.

2 Significant at the 1 per cent level.

3 The Deakin Wellbeing Index measures subjective wellbeing. It comprises seven questions relating to satisfaction with life domains, such as 'health' and 'standard of living'. A considerable body of research has demonstrated that most people are satisfied with their own life. In Western nations, the average value for population samples is about 75 percentage points of satisfaction. That is, on a standardised scale from 0 (completely dissatisfied) to 100 (completely satisfied), the average person rates their level of life satisfaction as 75. The normative range of wellbeing is tightly grouped around the average, between from about 73 to 76 points. Scores of below 65 signal individuals whose personal wellbeing might be at risk. 
farm and farmer variables, and this result is significant across all basin regions studied (unlike findings for other influences, which are often region/industry specific). Although other factors - such as farmer age, years farmed, type of farm, water entitlements, irrigated farm size, and technology adopted-do play a significant part in farm decisions, the influences of these variables differ from region to region.

The 2008-09 surveys in the GMID and Riverland asked irrigators how and where they planned to invest after selling their water entitlement. One-third of GMID irrigators and 40 per cent of Riverland irrigators planned to reduce debt, while the next largest response was off-farm investment (Figure 17.1) (Wheeler et al. 2010b). Only a small number of irrigators planned to use the funds for on-farm investment. Set in the context of the Basin drought, these results make intuitive sense. About one-third of irrigators in both communities suggested that they would spend the funds locally if they did sell water.

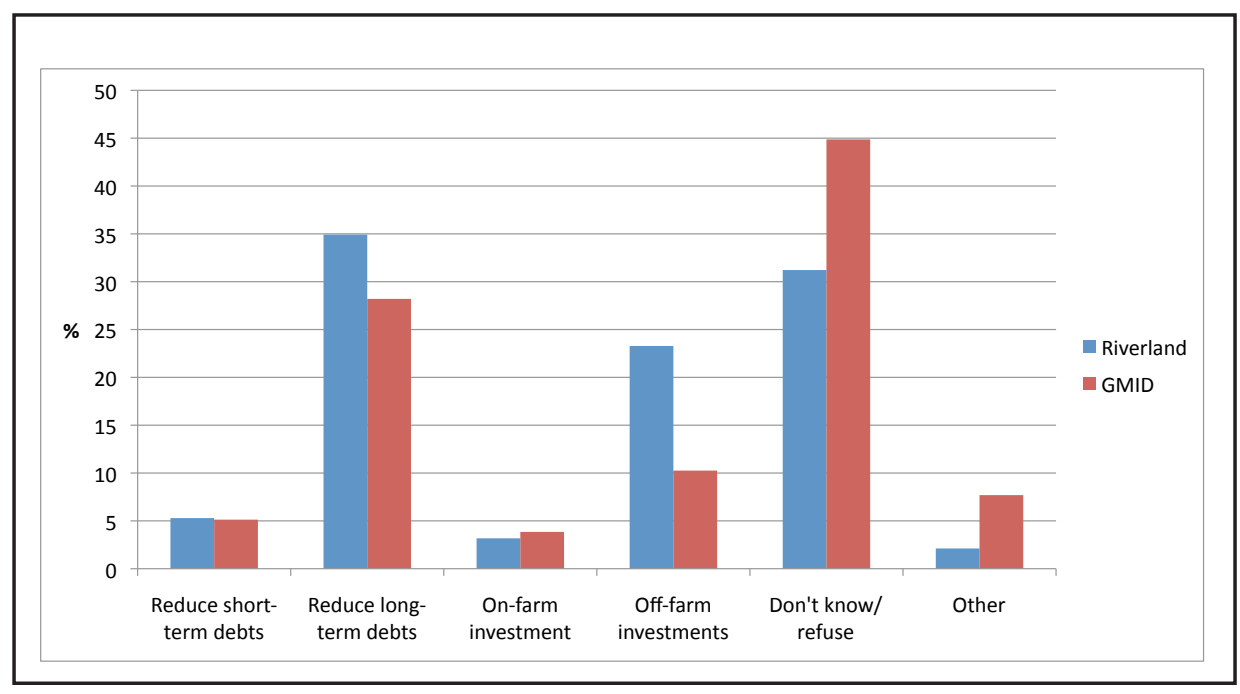

Figure 17.1 Plans of where to invest after selling water, 2008-09

What irrigators intend to do with the proceeds of water sales has shifted significantly over time. Bjornlund (1999) asked entitlement sellers in the GMID and the Riverland during the 1994-97 period how they had spent the proceeds from their water sales. Within the GMID it was found that 63 per cent put the money towards general revenue, 26 per cent towards debt reduction, 20 per cent to improve their irrigation and drainage system, and 11 per cent to purchase other assets such as machinery and land. In the Riverland, 27 per cent used the proceeds to improve their irrigation system, 17 per cent for debt reduction, 12 per cent to buy other farm assets and 44 per cent put the proceeds towards general revenue. 


\section{Will Sufficient Willing Sellers Continue to Come Forward?}

The future success of the Restoring the Balance program depends on securing enough water sales from willing irrigators in targeted regions to meet the environmental watering requirements of the Guide. Surveys of irrigators in 2008-09 suggest that between 40 and 60 per cent of irrigators in the Riverland and GMID stated they have not thought about selling water to the Government at all. Table 17.3 indicates that about 30-40 per cent of irrigators would consider selling their water entitlements, but only if they were offered 'substantially' more than market prices. In the Riverland in 2008-09, the minimum average price suggested by irrigators for a water entitlement per megalitre was just less than \$2700, while GMID irrigators' minimum average was a little more than $\$ 1900$ (Wheeler et al. 2010b).

Wheeler et al. (2010b) estimated the total water volume that irrigators were planning to sell to the Government in 2008-09. It is of some concern that the estimated volume was only about half of what the Government plans to buy back If right, these results suggest that the Australian government will need to pay a higher price for water entitlements into the future than it has paid in the past if it wishes to secure the volumes of water it needs for the environment.

A caveat to our findings is that these estimates have been based on static one-year responses in a period of extreme drought and low commodity prices. Irrigators' past stated willingness to sell could change considerably if farm conditions improve (or worsen). The dynamic aspect of changing preferences for selling water is an area deserving further investigation. If willingness to sell water entitlements has fallen as the drought eases then the Government might need to pursue different approaches or restructure the buyback in order to encourage future participation and reasonable bids from irrigators in the future.

\section{Conclusions}

The release of the Guide to the proposed Basin Plan has aggravated a long-term distrust held within some irrigation communities about the permanent transfer of water entitlements from their regions. Irrigation communities have historically been wary of selling water entitlements, although this wariness appears to be easing over time. While trading in allocation water has grown considerably, the growth of water-entitlement trading has been considerably slower. Studies of irrigators' attitudes towards trading show a growing acceptance of the benefits of water markets over time, although often vocal dissenters persist within communities. Irrigators selling water (or exiting farming) are frequently motivated by debt considerations. 
It is important to realise, however, that debt management is not the sole (or perhaps the main) rationale for irrigators selling water permanently. Values, attitudes and wellbeing of irrigators appear to play a more central role. While increasing farm debt does appear to be correlated with lower personal wellbeing, financial stress is only one attribute of personal wellbeing.

\section{References}

Australian Bureau of Agricultural and Resource Economics (ABARE) 2009, Irrigated Agriculture in the Murray-Darling Basin: A farm level analysis by region and industry, Australian Bureau of Agricultural and Resource Economics, Canberra.

Bjornlund, H. 1999, Water trade policies as a component of environmentally, socially and economically sustainable water use in rural southeastern Australia, D.Phil. Thesis, University of South Australia, Adelaide.

Bjornlund, H. 2000, Water market activities, outcomes and perceptions; section 4: permanent trade along the Murray and Murrumbidgee rivers - New South Wales, Second Steering Committee Report for LWRRDC Project USA 3, $<$ www.prres.net $>$

Bjornlund, H. 2002, 'The socio-economic structure of irrigation communitieswater markets and the structural adjustment process', Journal of Rural Society, vol. 12, no. 2, pp. 123-45.

Bjornlund, H. 2004, 'Formal and informal water markets - drivers of sustainable rural communities?', Water Resources Research, vol. 40, no. W09S07.

Bjornlund, H. 2005, 'Irrigators and the new policy paradigm-an Australian case study', Water Policy, vol. 7, no. 6, pp. 581-96.

Bjornlund, H. 2006, 'Can water markets assist irrigators managing increased supply risk? Some Australian experiences', Water International, vol. 31, no. 2 , pp. $221-32$.

Bjornlund, H. 2007, The monitoring of, and reporting on, water trading within the Goulburn-Murray Irrigation District (2), Industry Partner Report No. 6, ARC Linkage Grant Water Scarcity and Rural Social Hardship - Can water markets alleviate the problems?, University of South Australia, Adelaide, <www.prres.net>

Bjornlund, H. and Rossini, P. 2008, Are the fundamentals emerging for more sophisticated water market instruments?, Fourteenth Annual Conference of the Pacific Rim Real Estate Society, Kuala Lumpur, January, <www.prres.net> 
Bjornlund, H. and Rossini, P. 2010, Climate change, water scarcity and water markets - implications for farmers' wealth and farm succession, Sixteenth Pacific Rim Real Estate Society Conference, Wellington, <www.prres.net>

Edwards, J., Bjornlund, H. and Cheers, B. 2007, The impact of trading of water out of districts: a case study of the Kerang region in Victoria, Industry Partner Report No. 5, ARC Linkage Grant Water Scarcity and Rural Social HardshipCan water markets alleviate the problems?, University of South Australia, Adelaide, <www.prres.net>

Fenton, M. 2006, The social implications of permanent water trading in the LoddonCampaspe Irrigation Region of northern Victoria, May, Report Prepared for North Central Catchment Management Authority, Huntly, Vic.

Kuehne, G., Bjornlund, H. and Loch, A. 2010, Why do farmers make non-profit decisions - investigating decisions made during drought, RIRDC Publication No. 10/075, Rural Industries Research and Development Corporation, Canberra.

Marsden Jacob Associates 2010, Delivering the Basin Plan: Economic and social profiles of Murray Darling Basin communities: Appendix 3b: Irrigator survey technical report, July, Report for Murray-Darling Basin Authority, Canberra.

National Water Commission 2010, The Impacts of Water Trading in the Southern Murray-Darling Basin: An economic, social and environmental assessment, National Water Commission, Canberra.

Tisdell, J. G. and Ward, J. R. 2003, 'Attitudes toward water markets: an Australian case study', Society and Natural Resources, vol. 16, pp. 61-75.

Wheeler, S., Bjornlund, H., Shanahan, M. and Zuo, A. 2009, 'Who trades water? Evidence of the characteristics of early adopters in the Goulburn-Murray Irrigation District, Australia 1998-99', Agricultural Economics, vol. 40, pp. $631-43$.

Wheeler, S., Bjornlund, H., Zuo, A. and Shanahan, M. 2010a, 'The changing profile of water traders in the Goulburn-Murray Irrigation District, Australia between 1998-99 and 2003-06', Journal of Agricultural Water Management, vol. 97, no. 9, pp. 1333-43.

Wheeler, S., Lane Miller, C., Zuo, A. and Bjornlund, H. 2010b, Estimating southern Murray Darling Basin irrigators' willingness to sell water entitlements to the Federal Government, CRMA Working Paper, November, University of South Australia, Adelaide. 